\title{
Banana Cultivars Microshoot Induction and Plantlet Formation Using Cytokinin and Auxin
}

\author{
Sugiyono $^{1 *}$, Prita Sari Dewi ${ }^{2}$ and Rendie Prasetyo ${ }^{1}$ \\ ${ }^{1}$ Department of Botany, Faculty of Biology, Universitas Jenderal Soedirman, Purwokerto, Indonesia; \\ ${ }^{2}$ Department of Agrotechnology, Faculty of Agriculture, Universitas Jenderal Soedirman, Purwokerto, Indonesia
}

*Corresponding author: sugiyono@unsoed.ac.id; gieks_sugiyono@hotmail.com

\begin{abstract}
Banana is a horticultural plant with very high potentials, which contains carbohydrates and vitamins that are useful in fulfilling people's food and nutritional needs. Hence, this study aims to produce superior banana seedlings and develop a protocol for their mass production using a plant in vitro culture technique. This was a two stage-experiment i.e. microshoot production and plantlet formation. The result showed that Gebyar cultivar produced more shoots than the Kepok Kuning cultivar, with an average of 4.25 microshoots explant ${ }^{-1}$. However, Kepok Kuning produced more leaves than Gebyar, with an average of 4.64 leaves plantlet $^{-1}$. Banana shoots cultured on the media containing Indole-3-acetic acid (IAA) at a concentration of $2.5 \mu \mathrm{M}$ produced the highest leaves number. Meanwhile, those cultured on the media containing 1-Naphthalenesacetic acid (NAA) at a concentration of $7.5 \mu \mathrm{M}$ produced the highest roots number. A Murashige and Skoog (MS) medium supplemented with 6-Benzylaminopurine (BAP) up to $30 \mu \mathrm{M}$ and the one supplemented with $7.5 \mu \mathrm{M}$ of NAA are suitable for Kepok Kuning and Gebyar cultivars micropropagation with regard to microshoot induction and plantlet formation, respectively.
\end{abstract}

Keywords: BAP; Gebyar; in vitro culture; Kepok Kuning; NAA; sword sucker

Cite this as: Sugiyono, Dewi, P. S., \& Prasetyo, R. (2021). Banana Cultivars Microshoot Induction and Plantlet Formation Using Cytokinin and Auxin. Caraka Tani: Journal of Sustainable Agriculture, 36(2), 249-258. doi: http://dx.doi.org/10.20961/carakatani.v36i2.50425

\section{INTRODUCTION}

Banana is one of the horticultural plants with great potential due to its high nutritional value and being an income source for local farmers. This crop is also importantly cultivated by the people living in tropical countries and it is the world's fourth agricultural commodity after rice, wheat and maize (Satuhu and Supriyadi, 2007). According to Singh et al. (2014), almost all modern edible bananas originate from two wild diploid species, namely Musa acuminata designated as genotype AA and Musa balbisiana as BB. Some are found to have an AA or AB genotype but the vast majority is triploid. Many domesticated bananas are proven to be triploid with a genotype of $\mathrm{AAA}, \mathrm{AAB}$ or $\mathrm{ABB}$. There are also seedless cultivated $A A$ and $A B$ diploid, AAAA, AAAB, AABB and ABBB tetraploids.

Indonesia's total banana production has been relatively stable in the last five years with an average of 7.202 million tons year ${ }^{-1}$. This reached 7.280 million tons in 2019, with only $0.22 \%$ increase from 2015 (BPS - Statistics Indonesia, 2020). The Directorate of Horticultural Production Development and the Horticulture Research and Development Center prioritize banana as one of the fruits to be developed and studied. Production in the last 10 years has been influenced by plant pests and diseases

\footnotetext{
* Received for publication April 15, 2021

Accepted after corrections May 22, 2021
} 
(Prasetyo et al., 2020), especially the outbreak of Panama disease (Fusarium wilt), Bacterium Blood disease caused by Pseudomonas celebensis and Moko disease (bacterial wilt) (Mondal et al., 2012; Ploetz, 2015). Furthermore, leaf wilt diseases such as Panama caused by the fungus Fusarium oxysporum Schlecht sp. Cubans and Moko caused by the bacterium Raisotonia solanacearum are the most dangerous to bananas. The two pathogens are soil-borne and easily transmitted, which enhance their spread to almost all banana plantations in Indonesia (Ploetz, 2015). They form chlamydospores in the soil which survive for a very long time (Ghag et al., 2015), therefore making the control of the diseases produced to be extremely difficult.

Most consumable bananas are triploid and sterile, making genetic improvement through conventional crossing difficult. Consequently, the integration of in vitro technique for genetic improvement is crucial. The provision of superior banana seedlings is an important strategy to increase production. High-quality seedlings can be developed using in vitro culture technique. The factors influencing this process include plant genetic composition and its expression, nutrition, physical growth factors and the utilization of Plant Growth Regulators (PGRs) and vitamins (Amoo and van Staden, 2013; Kadhimi et al., 2014).

The three banana cultivars used in this study were Ambon Nangka (Musa acuminata $\times$ Musa balbisiana AAB), Gebyar (Musa acuminata $\times$ Musa balbisiana AAB) and Kepok Kuning (Musa acuminata $\times$ Musa balbisiana ABB). They are widely cultivated in Indonesia, especially in Banyumas Regency, Central Java. Studies related to the microshoot induction of bananas with $\mathrm{AAB}$ and $\mathrm{ABB}$ genotypes were previously carried out by Hui et al. (2012), Kindimba and Msogoya (2014) and Yatim (2016). During the induction of axillary shoots growth, 6-Benzylaminopurine (BAP) and kinetin are commonly used due to being very active, longlasting, easily translocated, stable and heat resistant. Meanwhile, cytokinins and auxins addition to the in vitro culture triggers cell division to form new cells, controls apical dominance and inhibits tissue aging (Schaller et al., 2014; Feng et al., 2017). The success of banana shoot multiplication using BAP has been reported by Ali et al. (2011); Vishnevetsky et al. (2011) and Govindaraju et al. (2012). In the plantlet formation phase, auxins such as
Indole-3-acetic acid (IAA), Indole-3-butyric acid (IBA) and 1-Naphthalenesacetic acid (NAA) are used. Banana shoots rooting in in vitro culture has been successfully carried out by adding auxins according to Muller and Leyser (2011); Müller et al. (2015) and Hossain et al. (2016).

This study aims to produce superior banana seedlings and develop a protocol for their mass production using in vitro plant culture technique, as well as to evaluate the influence of cytokinins and auxins types and concentrations on the three banana cultivars plantlet formation. The mass production of disease-free plantlets provides a means whereby plants including bananas (Daniells, 2007), are improved for sustainable cultivation (Viljoen et al., 2004).

\section{MATERIALS AND METHOD}

\section{Plant material}

The materials used in the microshoot induction phase were the sword suckers, i.e., vigorous shoots arising from the rootstock of banana plants, of three banana cultivars namely Gebyar, Ambon Nangka and Kepok Kuning. They were obtained from a local banana nursery in Purwokerto City, Banyumas Regency, Central Java, Indonesia. The use of sword sucker in banana micropropagation was also reported by Ali et al. (2011) and Govindaraju et al. (2012). During the plantlet formation phase, the Gebyar and Kepok Kuning cultivars microshoots obtained from the induction phase were used.

\section{Explant preparation}

Explant isolation was carried out by selecting banana sword suckers with an approximate size of $7 \mathrm{~cm} \times 6 \mathrm{~cm} \times 15 \mathrm{~cm}$. The shoots were excised from the sword suckers and cut into $2 \mathrm{~cm} \times 2 \mathrm{~cm}$ $\times 2 \mathrm{~cm}$ size and subsequently soaked in distilled water. Then, the explants were washed using sterile distilled water supplemented with few drops of Tween 20 to reduce surface tension. They were sterilized in a Laminar Air Flow cabinet (LAF) through immersion in 70\% ethanol for 2 minutes, followed by double immersion in $0.2 \% \mathrm{HgCl}_{2}$ for five minutes. Sinha and Deka (2016) reported that $\mathrm{HgCl}_{2}$ and Tween as effective chemicals for sterilizing Malbhog banana cultivar. Next, the explants were rinsed in sterile distilled water for 30 seconds and this was repeated three times. Each side of the sterilized explants was cut to remove residues and dead tissue which resulted in $1 \mathrm{~cm} \times 1 \mathrm{~cm} \times 1 \mathrm{~cm}$ explant 
size as described by Govindaraju et al. (2012). Furthermore, they were inoculated and grown on a Murashige and Skoog (MS) medium supplemented with $15 \mu \mathrm{M}$ BAP for axillary shoot induction, then the cultures were incubated at $24{ }^{\circ} \mathrm{C}$ with continuous light.

\section{Microshoots induction and plantlet formation}

MS basal medium (Sigma-Aldrich-M5519) supplemented with $20 \mathrm{~g} \mathrm{~L}^{-1}$ sucrose, $2 \mu \mathrm{M}$ IAA (Sigma-Aldrich-I2886), BAP and kinetin (SigmaAldrich-K0753) as treatments, solidified with $2.5 \mathrm{~g} \mathrm{~L}^{-1}$ phytagel (Sigma-Aldrich-P8169), was used for microshoot induction. The treatments were arranged in a Spit-Split Plot Design, with three replications. The main plot was banana cultivars consisting of Ambon Nangka, Gebyar and Kepok Kuning. The sub-plot was type of cytokinin consisting of BAP (Sigma-AldrichB3408) and kinetin (Sigma-Aldrich-K0753). The sub-sub-plot was concentration of cytokinin consisting of $15,20,25$ and $30 \mu \mathrm{M}$. The cytokinin concentrations used are a modification of the results reported by Prayoga and Sugiyono (2010). The explants were sub-cultured into the same medium after six weeks of culturing.

For plantlet formation, microshoots were transferred to the root induction medium, namely an MS basal medium supplemented with $20 \mathrm{~g} \mathrm{~L}^{-1}$ sucrose and solidified with $0.2 \%$ phytagel. The treatments were arranged in a Split-SplitPlot Design, with three replications. The main plot was banana cultivars which consisted of

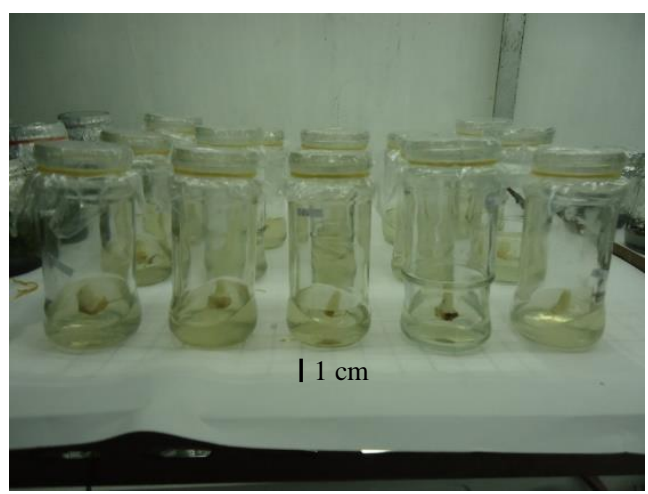

A.
Gebyar and Kepok Kuning, while the subplot was an auxin type consisting of IAA, IBA (Sigma-Aldrich-I5386) and NAA (SigmaAldrich-N0640). The sub-sub-plot was auxin concentration consisting of $2.5 \mu \mathrm{M}, 5.0 \mu \mathrm{M}$, 7.5 $\mu \mathrm{M}$ and $10 \mu \mathrm{M}$. NAA and IBA had been reported as the best treatments for banana culture in rasthali cultivars (Govindaraju et al., 2012). The variables observed in this study were the formation of microshoots and plantlets. The parameters measured include the number of shoots, the number of leaves and the number of roots.

\section{Data analysis}

The data obtained were analyzed using an Analysis of Variance (ANOVA), followed by the Honestly Significant Difference (HSD) test with a confidence level of $95 \%$.

\section{RESULTS AND DISCUSSION}

\section{Microshoots induction}

The in vitro culture of several banana cultivars has been successfully carried out, where explants were planted in the treatment medium (Figure 1). New shoots developed after six weeks of incubation (Figure 2) and few microshoots appeared after several sub-cultures (Figure 3). In microshoot induction, Gebyar and Kepok Kuning produced more microshoots than Ambon Nangka. Hence, Ambon Nangka did not proceed to the plantlet formation stage due to its low microshoot production.

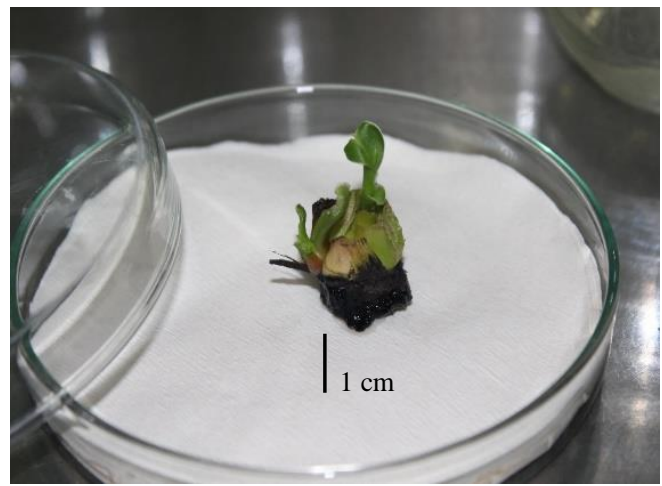

B

Figure 1. The effect of different banana cultivars and cytokinin types and concentrations on microshoot formation. (A) The appearance of banana explant on treatment medium, (B) Gebyar microshoot development on MS medium supplemented with BAP

The small number of microshoots produced was probably due to the PGR concentration used (Bordoloi, 2016), the explants physiological conditions such as apical dominance (Bhende and Kurien, 2015; Kebrom, 2017) and the culture period (Rahman et al., 2013). The cytokinin 
concentration added to the media did not stimulate new shoots formation. According to Ahmed et al. (2014), the time required for explant shoot formation on a combined media (BAP and IAA) was slower than on the media containing only BAP or in combination with kinetin. This result is in agreement with the report by Buah et al. (2010) and Ashraf et al. (2014). BAP's better effect on shoot formation compared to kinetin may be attributed to its high stability within in vitro cultures, because it is not easily broken down and therefore persists in the medium. Possibly, the BAP amount conjugated in the medium was smaller than that of other growth regulators, leading to the presence of more BAP in their free or ionized forms, which were made readily available to plant tissues from the medium (Buah et al., 2010).

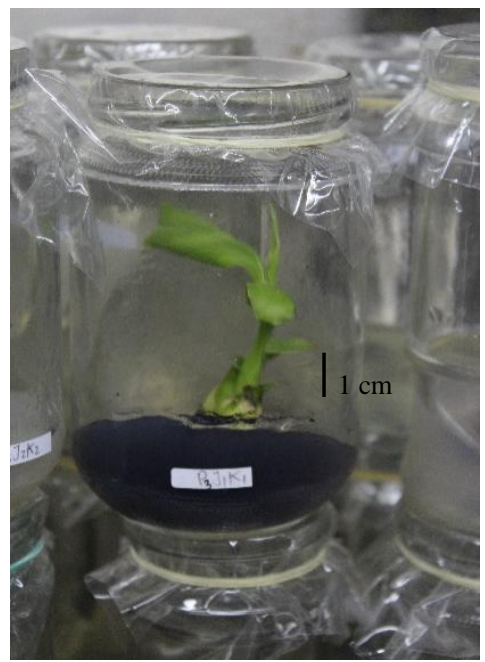

A.
Furthermore, the explants in this study were taken at the dry season peak, hence it is suggested that they had high abscisic acid (ABA) content as a response to water stress. ABA is widely known as a stress hormone, and its level increases in the presence of stress, including water stress (Hu et al., 2016). The high concentration of endogenous ABA inhibits microshoots formation and growth (Feng et al., 2012). These conditions are thought to have influenced explants growth and microshoots development. To solve this problem, an extremely high cytokinin concentration have to be used to break the dormancy caused by ABA, which in turn stimulates microshoots development and growth (Goggin et al., 2015; Qiu et al., 2019). Nuraini et al. (2016) and Prasetyo et al. (2020) stated high cytokinin utilization breaks dormancy and initiates shoot growth.

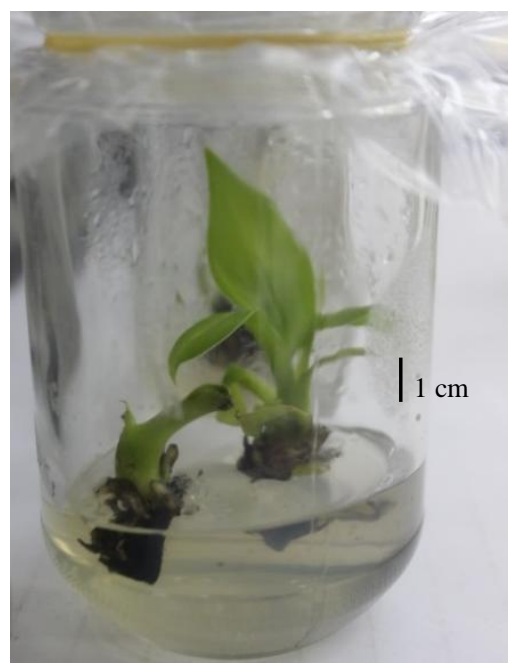

B.

Figure 2. The appearance of banana microshoot formation. (A) Axillary bud development in banana sword sucker explants. (B) Development of banana sword sucker with split open treatment in sub-culture media

The sword sucker explants used were grown intact and not split open, hence, the apical shoots might produce high endogenous auxin and inhibited lateral shoot growth. This inhibition of shoot growth by auxin was also reported by Kebrom (2017). Moreover, apical dominance breakage requires high exogenous cytokinin concentrations (Nuraini et al., 2016; Prasetyo et al., 2020). It is suspected that the exogenous cytokinin level added to the in vitro culture did not break the apical dominance as reported by Müller et al. (2015) and Ngomuo et al. (2014).

\section{Plantlet formation}

The shoot formation and root induction aimed to form plantlets that have both leaves and roots. The microshoots were separated individually from the original clump and then transferred to the treatment media. At the plantlet formation phase, shoot morphogenesis was influenced by banana cultivar (Table 1) and the interaction between the cultivar and auxin type used (Table 2). Gebyar cultivar produced more microshoots compared to Kepok Kuning and on average, it produced 4.25 axillary buds explant ${ }^{-1}$. The difference in plants' genotypic 
responses is observed in their ability to grow and regenerate. Each genotype has different abilities regarding axillary shoot growth, shoot number and rooting emergence (Basri, 2016).

Table 1. The average number of shoots formed

\begin{tabular}{cc}
\hline $\begin{array}{c}\text { Types of } \\
\text { cultivars }\end{array}$ & $\begin{array}{c}\text { The number of } \\
\text { axillary buds }\end{array}$ \\
\hline Gebyar & $4.25^{\mathrm{a}}$ \\
Kepok Kuning & $1.47^{\mathrm{b}}$ \\
\hline
\end{tabular}

Note: Numbers followed by the same letters show a significant difference in DMRT $(\leq 0.05)$

Gebyar cultivars planted on a media containing NAA produced the greatest shoots number (5.7 shoots explant $\left.{ }^{-1}\right)$, although this treatment was not significantly different from that of the media containing IBA (Table 2). PGR treatment is used to stimulate cell proliferation and differentiation through organogenesis or embryogenesis (Méndez-Hernández et al., 2019).
Not all cells in plant tissue respond to PGR, a cell only responds at a particular stage in the plant growth cycle (Tréhin et al., 1998; Schaller et al., 2014). Besides plant genotypes, explant's physiological conditions such as meristematic ability to grow and cells or tissues growth status determines bud regeneration's success. It is also related to cell metabolism, availability of endogenous PGR and the activity of genes controlling growth and development (Pillay and Tenkouano, 2011; Feng et al., 2012; Remakanthan et al., 2014).

Table 2. The average shoot number formed by two banana cultivars with different types of auxin

\begin{tabular}{cccc}
\hline \multirow{2}{*}{ Type of cultivars } & \multicolumn{3}{c}{ Type of auxin } \\
\cline { 2 - 4 } & NAA & IBA & IAA \\
\hline Gebyar & $5.75^{\mathrm{a}}$ & $4.58^{\mathrm{a}}$ & $2.42^{\mathrm{b}}$ \\
Kepok Kuning & $1.18^{\mathrm{b}}$ & $1.58^{\mathrm{b}}$ & $1.67^{\mathrm{b}}$ \\
\hline
\end{tabular}

Note: Numbers followed by the same letters show a significant difference in DMRT $(\leq 0.05)$

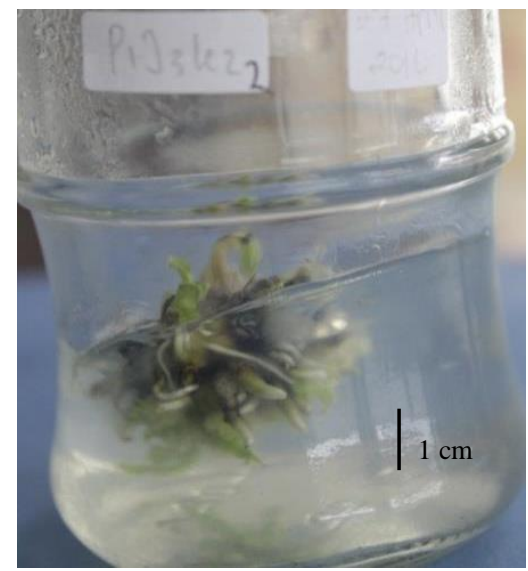

B.

Figure 3. The effect of auxin types and concentration with different banana cultivars on the number of shoots formation. (A) Kepok Kuning cultivar with an added $2.5 \mu$ M IAA.

(B) Gebyar cultivar with an added 5.0 $\mu$ M NAA

Leaf formation in the banana plantlet formation phase was controlled by the cultivar used and the interaction between the growth regulator type and PGR concentration used. Kepok Kuning produced more leaves than Gebyar, by producing 4.64 leaves plantlet ${ }^{-1}$ on average (Table 3). IAA utilization in culture media showed a significantly different effect on the number of leaves formed. Banana shoots grown on the media supplemented with $2.5 \mu \mathrm{M}$ IAA produced the greatest number of leaves, namely 5.5 leave plantlet ${ }^{-1}$. Shoots number is inversely related to the number of leaves formed. The greater the number of shoots produced, the smaller the number of leaves per shoot formed (Figure 4).

Table 3. The average number of leaves formed by two banana cultivars

\begin{tabular}{cc}
\hline Types of cultivars & Number of leaves \\
\hline Gebyar & $1.75^{\mathrm{b}}$ \\
Kepok Kuning & $4.64^{\mathrm{a}}$ \\
\hline
\end{tabular}

Note: Numbers followed by the same letters show a significant difference in DMRT $(\leq 0.05)$ 


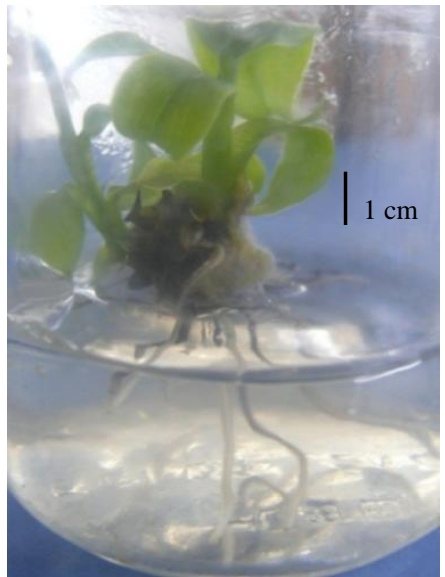

A.

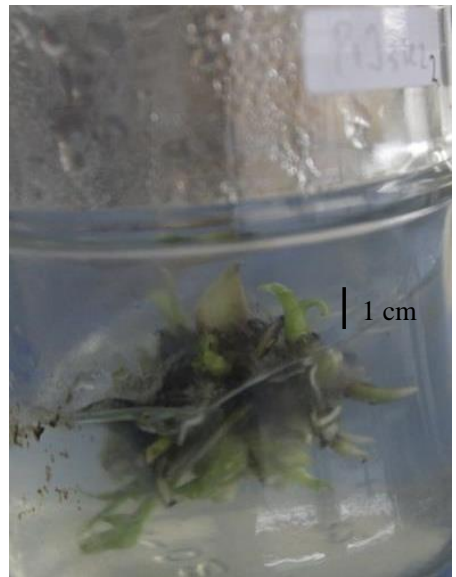

B.

Figure 4. The effect of auxin types and concentration with different banana cultivars on leaf formation. (A) Kepok Kuning cultivar with added $2.5 \mu$ M IAA. (B) Gebyar cultivar with added 5.0 $\mu \mathrm{M}$ NAA

Auxin plays a very important role in leaf growth, by stimulating the development of prospective leaf meristem tissue (Xiong and Jiao, 2019). The leaves number is closely related to photosynthesis and plant metabolism, as well as nutrient absorption, while their increased growth is due to accelerated cell division and differentiation (Keller et al., 2011; Novak and Whitehouse, 2013). Also, their growth and development processes require PGR, such as auxin and cytokinin, as well as other nutrients contained in the growing media. Auxin and cytokinin work synergistically in stimulating plant growth, hence IAA which is a type of auxin, IAA functions in regulating cell division and stimulating growth to ensure an increase in leaves number (Scarpella et al., 2010; Skupa et al., 2014). Auxin addition affects leaf growth, especially the vascular tissue's length (Aloni, 2010; Zazımalova et al., 2010).

Leaves are essential plant organs, especially for photosynthesis, which facilitate organic materials production and optimum growth. The higher the number of leaves, length and width, the higher the leaf mass per unit area (LMA). LMA is an important leaf morphological trait affecting photosynthesis (Ren et al., 2019). The relationship between leaf number and individual size has metabolic and mechanical consequences that influence energy balances and carbon uptake at the whole plant level. In addition, it is also crucial to light interception and net carbon gain (Sun et al., 2019).
Root induction was carried out at the final stage of plant in vitro culture. When axillary shoots emerged, they were subsequently subcultured on rooting media. Banana root formation was influenced by the interaction between the type of auxins used and their concentration. Although the addition of the three auxin types, namely IBA, NAA and IAA, did not show a significantly different effect on roots number. Generally, NAA demonstrated quite better results and produced the highest roots number compared to the other two auxins (Table 4). Banana shoots grown on the media containing NAA at a concentration of $7.5 \mu \mathrm{M}$ produced the highest roots number (13.3 roots plantlet ${ }^{-1}$ ) (Figure 5).

Table 4. Interaction between auxin type and concentration on the plantlet formation

\begin{tabular}{|c|c|c|c|}
\hline $\begin{array}{c}\text { Type of } \\
\text { auxin }\end{array}$ & $\begin{array}{l}\text { Concentration } \\
\text { of auxin }(\mu \mathrm{M})\end{array}$ & $\begin{array}{c}\text { Number of } \\
\text { leaves }\end{array}$ & $\begin{array}{l}\text { Number of } \\
\text { roots }\end{array}$ \\
\hline \multirow{4}{*}{ IAA } & 2.5 & $5.50^{\mathrm{a}}$ & $4.50^{\mathrm{bc}}$ \\
\hline & 5.0 & $2.17^{\mathrm{abc}}$ & $5.67^{\mathrm{bc}}$ \\
\hline & 7.5 & $2.17^{\mathrm{abc}}$ & $3.83^{\mathrm{bc}}$ \\
\hline & 10.0 & $3.83^{\mathrm{abc}}$ & $3.17^{\mathrm{bc}}$ \\
\hline \multirow{4}{*}{ IBA } & 2.5 & $2.00^{\mathrm{abc}}$ & $4.67^{b c}$ \\
\hline & 5.0 & $5.17^{\mathrm{ab}}$ & $7.00^{\mathrm{bc}}$ \\
\hline & 7.5 & $3.33^{\mathrm{abc}}$ & $6.17^{\mathrm{bc}}$ \\
\hline & 10.0 & $3.17^{\mathrm{abc}}$ & $4.17^{\mathrm{bc}}$ \\
\hline \multirow{4}{*}{ NAA } & 2.5 & $1.50^{\mathrm{bc}}$ & $6.17^{b c}$ \\
\hline & 5.0 & $1.17^{\mathrm{c}}$ & $2.33^{\mathrm{c}}$ \\
\hline & 7.5 & $4.67^{\mathrm{abc}}$ & $13.33^{\mathrm{a}}$ \\
\hline & 10.0 & $3.83^{\mathrm{abc}}$ & $9.67^{\mathrm{ab}}$ \\
\hline
\end{tabular}

Note: Numbers followed by the same letters show a significant difference in DMRT $(\leq 0.05)$ 


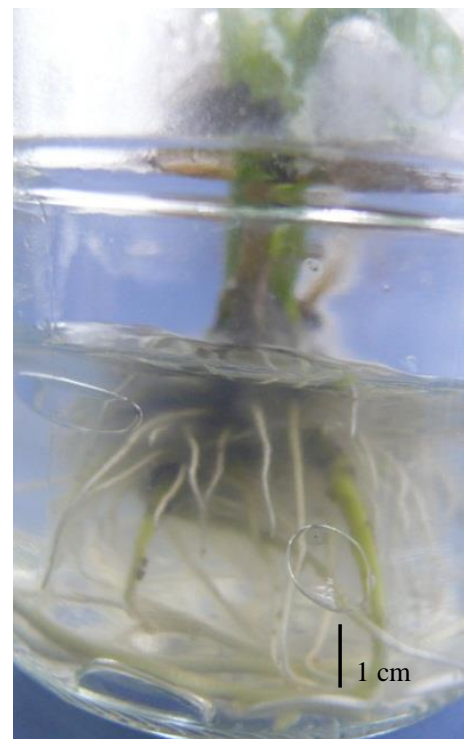

Figure 5. The effect of auxin types and concentration with different banana cultivars on roots' formation after a $7.5 \mu \mathrm{M}$ NAA treatment

At low concentrations, IAA causes shoots and roots elongation, but at a higher concentration, it inhibits the elongation (Pamungkas, 2015; Lathyfah and Dewi, 2016). According to Govindaraju et al. (2012) and Zhao (2014), NAA in low concentrations produced a higher roots number. Also, root's formation is related to the endogenous auxin and cytokinin contents in plant tissue. Therefore, lower auxin concentration is suggested to be used in inducing rooting on a nicely growing shoot.

\section{CONCLUSIONS}

Gebyar cultivar produced more shoots than Kepok Kuning, with an average of 4.25 microshoots explant ${ }^{-1}$. However, Kepok Kuning produced more leaves than Gebyar, with an average of 4.64 leaves plantlet ${ }^{-1}$. The media containing IAA with a concentration of $2.5 \mu \mathrm{M}$ produced the highest leaves number. Banana shoots that were cultured on a media containing NAA at a concentration of $7.5 \mu \mathrm{M}$ produced the highest roots number. Besides, good acclimatization to produce ready-to-plant seedlings and a study to optimize acclimatization conditions to provide a higher seedling survival rate are needed. The mass production of disease-free plantlets is expected to meet the increasing demand for banana seeds to increase the national production scale.

\section{ACKNOWLEDGEMENT}

The authors are grateful to the Rector of Universitas Jenderal Soedirman and the Ministry of Research, Technology and Higher Education for the funding provided through Riset Unggulan Perguruan Tinggi (Grant No. 2193).

\section{REFERENCES}

Ahmed, S., Sharma, A., Singh, A. K., Wali, V. K., \& Kumari, P. (2014). In vitro multiplication of banana (Musa sp.) cv. Grand Naine. African Journal of Biotechnology, 13(27), 2696-2703. https://doi.org/10.5897/ajb2014.13750

Ali, A., Sajid, A., Naveed, N. H., Majid, A., Saleem, A., Khan, U. A., Jafery, F. I., \& Naz, S. (2011). Initiation, proliferation and development of micropropagation system for mass scale production of banana through meristem culture. African Journal of Biotechnology, 10(70), 15731-15738. Retrieved from https://www.ajol.info/index. php/ajb/article/view/97536

Aloni, R. (2010). The induction of vascular tissues by auxin. In: Davies P.J. (eds) Plant Hormones. Dordrecht: Springer. https://doi. org/10.1007/978-1-4020-2686-7_22

Amoo, S. O., \& van Staden, J. (2013). Influence of plant growth regulators on shoot proliferation and secondary metabolite production in micropropagated Huernia hystrix. Plant Cell, Tissue and Organ Culture, 112, 249-256. https://doi.org/10.1007/s11240012-0230-x

Ashraf, M. F., Aziz, M. A., Kemat, N., \& Ismail, I. (2014). Effect of cytokinin types, concentrations and their interactions on in vitro shoot regeneration of chlorophytum borivilianum sant. \& fernandez. Electronic Journal of Biotechnology, 17(6), 275-279. https://doi.org/10.1016/j.ejbt.2014.08.004

Basri, A. H. (2016). Kajian pemanfaatan kultur jaringan dalam perbanyakan tanaman bebas virus. Agrica Ekstensia, 10(1), 64-73. Retrieved from https://www.polbangtanmedan .ac.id/pdf/Jurnal\%202016/Vol\%2010\%20No $\% 201 / 08 \% 20$ Arie.pdf

Bhende, S. S., \& Kurien, S. (2015). Sucker production in banana. Journal of Tropical Agriculture, 53(2), 97-106. Retrieved from 
http://jtropag.kau.in/index.php/ojs2/article/vie w/339

Bordoloi, N. D. (2016). Factors affecting in vitro shoot-tip culture of banana. Acta Horticulturae, 1113, 151-156. https://doi.org/ 10.17660/ActaHortic.2016.1113.22

BPS - Statistics Indonesia. (2020). SIMSPH Online, Survey Pertanian Hortikultura yang mencakup data produksi buah-buahan dan sayuran tahunan per kecamatan di seluruh wilayah Indonesia. Badan Pusat Statistik. Retrieved from https://www.bps.go.id/indica tor/55/62/1/produksi-tanaman-buah-buahan. html

Buah, J. N., Danso, E., Taah, K. J., Abole, E. A., Bediako, E. A., Asiedu, J., \& Baidoo, R. (2010). The effects of different concentrations cytokinins on the in vitro multiplication of plantain (Musa sp.). Biotechnology, 9(3), 343347. https://doi.org/10.3923/biotech.2010.343 .347

Daniells, J. (2007). Global banana disease management - Getting serious with sustainability and food security. Acta Horticulturae, 828, 411-416. https://doi.org/ 10.17660/ActaHortic.2009.828.43

Feng, J., Shi, Y., Yang, S., \& Zuo, J. (2017). Cytokinins. In J. Li, C. Li, S.M. Smith (Ed.), Hormone metabolism and signaling in plants, pp. 77-106. Academic Press. https://doi.org/ 10.1016/B978-0-12-811562-6.00003-7

Feng, J., Yuan, L., \& Bao-zhong, H. (2012). Overview of plant shooting branch. Journal of Northeast Agricultural University (English Edition), 19(2), 74-85. https://doi.org/10.1016 /s1006-8104(13)60042-2

Ghag, S. B., Shekhawat, U. K. S., \& Ganapathi, T. R. (2015). Fusarium wilt of banana: biology, epidemiology and management. International Journal of Pest Management, 61(3), 250-263. https://doi.org/10.1080/0967 0874.2015 .1043972

Goggin, D. E., Emery, R. J. N., Kurepin, L. V., \& Powles, S. B. (2015). A potential role for endogenous microflora in dormancy release, cytokinin metabolism and the response to fluridone in Lolium rigidum seeds. Annals of Botany, 115(2), 293-301. https://doi.org/ 10.1093/aob/mcu231
Govindaraju, S., Saravanan, J., Jayanthi, B., Nancy, D., \& Indra Arulselv, P. (2012). In vitro propagation of Banana (Musa sp.Rasthali variety) from sword suckers for its commercial production. Research in Plant Biology, 2(5), 1-6. Retrieved from https:// updatepublishing.com/journal/index.php/ripb/ article/view/2533

Hossain, M. A., Rubel, M. H., Nasiruddin, K. M., \& Evamoni, F. Z. (2016). Influence of BAP and NAA on in vitro plantlet regeneration of local and exotic banana cultivars. Journal of Bioscience and Agriculture Research, 6(2), 553-564. https://doi.org/10.18801/jbar.06021 6.66

Hu, B., Cao, J., Ge, K., \& Li, L. (2016). The site of water stress governs the pattern of ABA synthesis and transport in peanut. Scientific Reports, 6, 1-11. https://doi.org/10.1038/srep 32143

Hui, A. V., Bhatt, A., \& Keng, C. L. (2012). Micropropagation of Musa acuminata x Musa balbisiana cv. Pisang Awak (ABB genome) and three other cultivars. Pakistan Journal of Botany, 44(2), 777-780. Retrieved from http://www.pakbs.org/pjbot/PDFs/44(2)/46. pdf

Kadhimi, A. A., Alhasnawi, A. N., Mohamad, A., Yusoff, W. M. W., \& Zain, C. R. C. M. (2014). Tissue culture and some of the factors affecting them and the micropropagation of strawberry. Life Science Journal, 11(8), 484-493. Retrieved from http://www.lifesciencesite.com/lsj/life1108/06 3_23503life110814_484_493.pdf

Kebrom, T. H. (2017). A growing stem inhibits bud outgrowth - The overlooked theory of apical dominance. Frontiers in Plant Science, 8, 1-7. https://doi.org/10.3389/fpls.2017.018 74

Keller, C. P., Grundstad, M. L., Evanoff, M. A., Keith, J. D., Lentz, D. S., Wagner, S. L., Culler, A. H., \& Cohen, J. D. (2011). Auxininduced leaf blade expansion in Arabidopsis requires both wounding and detachment. Plant Signaling and Behavior, 6(12), 1997-2007. https://doi.org/10.4161/psb.6.12.18026

Kindimba, G., \& Msogoya, T. (2014). Effect of benzylaminopurine on in vivo multiplication 
of French plantain (Musa spp. AAB) cv. 'Itoke sege.' Journal of Applied Biosciences, 74(1), 6086-6090. https://doi.org/10.4314/jab. v74i1.1

Lathyfah, U., \& Dewi, E. R. S. (2016). Pengaruh variasi konsentrasi Indole Acetid Acid (IAA) terhadap pertumbuhan tunas pisang barangan (Musa acuminata L. triploid AAA.) dalam kultur in vitro. Bioma, 5(1), 32-42. https:// doi.org/10.26877/bioma.v5i1.1492

Méndez-Hernández, H. A., Ledezma-Rodríguez, M., Avilez-Montalvo, R. N., Juárez-Gómez, Y. L., Skeete, A., Avilez-Montalvo, J., De-LaPeña, C., \& Loyola-Vargas, V. M. (2019). Signaling overview of plant somatic embryogenesis. Frontiers in Plant Science, 10, 1-15. https://doi.org/10.3389/fpls.2019.00077

Müller, D., \& Leyser, O. (2011). Auxin, cytokinin and the control of shoot branching. Annals of Botany, 107(7), 1203-1212 https://doi.org/ 10.1093/aob/mcr069

Mondal, B., Ray, S. K., Misra, D. K., \& Khatua, D. C. (2012). Bacterial wilt of banana in West Bengal, India. International Journal of Plant Protection, 5(2), 227-231. Retrieved from http://researchjournal.co.in/online/IJPP/ IJPP\%205(2)/5_A-227-231.pdf

Müller, D., Waldie, T., Miyawaki, K., To, J. P. C., Melnyk, C. W., Kieber, J. J., Kakimoto, T., \& Leyser, O. (2015). Cytokinin is required for escape but not release from auxin mediated apical dominance. Plant Journal, 82(5), 874886. https://doi.org/10.1111/tpj.12862

Ngomuo, M., Mneney, E., \& Ndakidemi, P. (2014). The effect of bud splitting on suppression of apical dominance and inducing multiple buds development in banana shoot tip cultures of cv. 'Yangambi' (AAA) in Tanzania. American Journal of Experimental Agriculture, 4(12), 1853-1860. https://doi.org/ 10.9734/ajea/2014/7290

Novak, S. D., \& Whitehouse, G. A. (2013). Auxin regulates first leaf development and promotes the formation of protocorm trichomes and rhizome-like structures in developing seedlings of Spathoglottis plicata (Orchidaceae). AoB PLANTS, 5, 1-12. https://doi.org/10.1093/aobpla/pls053

Nuraini, A., Sumadi, S., \& Pratama, R. (2016).
Aplikasi sitokinin untuk pematahan dormansi benih kentang G1 (Solanum tuberosum L.). Kultivasi, 15(3), 202-207. https://doi.org/ 10.24198/kultivasi.v15i3.11765

Pamungkas, S. S. T. (2015). Pengaruh konsentrasi NAA dan BAP terhadap pertumbuhan tunas eksplan tanaman pisang cavendish (Musa paradisiaca L.) melalui kultur in vitro. Gontor AGROTECH Science Journal, 2(1), 31-45. https://doi.org/10.21111/agrotech.v2i1.295

Pillay, M., \& Tenkouano, A. (2011). Banana breeding progress and challenges. CRC Press.

Ploetz, R. C. (2015). Management of Fusarium wilt of banana: A review with special reference to tropical race 4. Crop Protection, 73, 7-15. https://doi.org/10.1016/j.cropro.2015.01.007

Prasetyo, R., Sugiyono, \& Prayoga, L. (2020). Induksi tunas mikro pisang kultivar ambon nangka (Musa sp.) secara in vitro. Vigor: Jurnal Ilmu Pertanian Dan Subtropika, 5(2), 45-50. Retrieved from https://jurnal.untidar. ac.id/index.php/vigor/article/view/3044

Prayoga, L., \& Sugiyono, S. (2010). Uji perbadaan media dan konsentrasi BAP terhadap pertumbuhan tunas pisang raja secara kultur in vitro. Agritech, 12(2), 8999. Retrieved from http://jurnalnasional.ump. ac.id/index.php/AGRITECH/article/view/990

Qiu, Y., Guan, S. C., Wen, C., Li, P., Gao, Z., \& Chen, X. (2019). Auxin and cytokinin coordinate the dormancy and outgrowth of axillary bud in strawberry runner. BMC Plant Biology, 19(1), 1-16. https://doi.org/10.1186 /s12870-019-2151-x

Rahman, S., Biswas, N., Hassan, M. M., \& Ahmed, M. G., Mamun, A. N. K., Islam, M. R., Moniruzzaman, M., \& Haque, M. E. (2013). Micro propagation of banana (Musa sp.) cv. Agnishwar by in vitro shoot tip culture. International Research Journal of Biotechnology, 4(4), 83-88. Retrieved from https://www.interesjournals.org/articles/micro -propagation-of-banana-musa-sp-cv-agnishwa r-by-in-vitro-shoot-tip-culture.pdf

Remakanthan, A., Menon, T. G., \& Soniya, E. V. (2014). Somatic embryogenesis in banana (Musa acuminata AAA cv. Grand Naine): Effect of explant and culture conditions. In vitro Cellular and Developmental Biology - 
Plant, 50(1), 127-136. https://doi.org/10.1007 /s11627-013-9546-4

Ren, T., Weraduwage, S. M., \& Sharkey, T. D. (2019). Prospects for enhancing leaf photosynthetic capacity by manipulating mesophyll cell morphology. Journal of Experimental Botany, 70(4), 1153-1165. https://doi.org/10.1093/jxb/ery448

Satuhu, S., \& Supriyadi, A. (2007). Pisang: budi daya, pengolahan, dan prospek pasar. Jakarta: Penebar Swadaya.

Scarpella, E., Barkoulas, M., \& Tsiantis, M. (2010). Control of leaf and vein development by auxin. Cold Spring Harbor Perspectives in Biology, 2(1), a001511. https://doi.org/ 10.1101/cshperspect.a001511

Schaller, G. E., Street, I. H., \& Kieber, J. J. (2014). Cytokinin and the cell cycle. Current Opinion in Plant Biology, 21, 7-15. https://doi.org/ 10.1016/j.pbi.2014.05.015

Singh, W. R., Singh, S. S., \& Karuna, S. (2014). Analysis of banana genome groups of wild and cultivated cultivars of Manipur, India using sScore card method. Advances in Applied Science Research, 5(1), 35-38. Retrieved from https://www.imedpub.com/articles/analysis-of -banana-genome-groups-of-wild-and-cultivate d-cultivars-ofmanipur-india-using-sscore-card -method.pdf

Sinha, S. K., \& Deka, A. C. (2016). Effect of osmotic stress on in vitro propagation of Musa sp. (Malbhog variety). African Journal of Biotechnology, 15(12), 465-471. https://doi. org/10.5897/ajb2015.14446

Skupa, P., Opatrny, Z., \& Petrasek, J. (2014). Auxin Biology: Applications and the Mechanisms Behind. In Nick, P., Opatrny Z. (Ed.) Applied Plant Cell Biology: Cellular Tools and Approaches for Plant Biotechnology. Berlin, Heidelberg: Springer. https://doi.org/10.1007/978-3-642-41787-0_3

Sun, J., Wang, M., Lyu, M., Niklas, K. J., Zhong, Q., Li, M., \& Cheng, D. (2019). Stem and leaf growth rates define the leaf size vs. number trade-off. AoB PLANTS, 11(6), plz063. https://doi.org/10.1093/aobpla/plz063

Tréhin, C., Planchais, S., Glab, N., Perennes, C., Tregear, J., \& Bergounioux, C. (1998). Cell cycle regulation by plant growth regulators: Involvement of auxin and cytokinin in the re-entry of Petunia protoplasts into the cell cycle. Planta, 206(2), 215-224. https://doi. org/10.1007/s004250050393

Viljoen, A., Kunert, K., Kiggundu, A., Escalant, J. V., \& Bornman, C.H. (2004). Biotechnology for sustainable banana and plantain production in Africa: The South African contribution. South African Journal of Botany, 70(1), 67-74. https://doi.org/10.1016/S0254-6299(15)30308 $-2$

Vishnevetsky, J., White, T. L., Palmateer, A. J., Flaishman, M., Cohen, Y., Elad, Y., Velcheva, M., Hanania, U., Sahar, N., Dgani, O., \& Perl, A. (2011). Improved tolerance toward fungal diseases in transgenic Cavendish banana (Musa spp. AAA group) cv. Grand Nain. Transgenic Research, 20, 61-72. https:// doi.org/10.1007/s11248-010-9392-7

Xiong, Y., \& Jiao, Y. (2019). The diverse roles of auxin in regulating leaf development. Plants, 8(7), 1-14. https://doi.org/10.3390/plants80 70243

Yatim, H. (2016). Multiplication of Raja Bulu banana (Musa paradisiaca L. AAB group) on several Benzyl Amino Purine (BAP) concentration by using in vitro method. Agroekoteknologi, 4(3), 1989-1995. Retrieved from https://www.neliti.com/publi cations/107456/multiplication-of-raja-bulubanana-musa-paradisiaca-l-aab-group-onseveral-benzy

Zazımalova, E., Murphy, A. S., Yang, H., Hoyerova, K., \& Hosek, P. (2010). Auxin transporters-why so many? Cold Spring Harbor Laboratory Press, 2(3), a001552. https://dx.doi.org/10.1101/cshperspect.a0015 52

Zhao, Y. (2014). Auxin biosynthesis. The Arabidopsis Book, 12(12), e0173. https:// doi.org/10.1199/tab.0173 